\title{
Paracoccidioidomycosis - description of two cases autochthonous in Ceará
}

\section{Authors}

Mônica Cardoso Façanha ${ }^{1}$ Anastácio de Queiroz Souza ${ }^{2}$ Vaulice Sales Café ${ }^{3}$ Bodo Wanke ${ }^{4}$

${ }^{1}$ Physician, Doctor in Pharmacology, Master in Infectious and Parasitary Diseases, Professor of

Infectious Diseases in Federal

University of Ceará.

${ }^{2}$ Physician at São José

Hospital of Infectious

Diseases, Professor of the

Department of Clinical

Medicine in Federal

University of Ceará.

${ }^{3}$ Physician, Chief of the

Microbiology Laboratory of

Walter Cantídio University

Hospital, Federal University

of Ceará.

${ }^{4}$ Physician, Titular Researcher of Evandro Chagas Institute of Clinical Research from Oswaldo Cruz Foundation, Rio de Janeiro-RJ.
Submitted on: 08/12/2009 Approved on: 10/31/2009

\section{Correspondence to:}

Mônica Cardoso Façanha, Rua Pinto Madeira 777/701. CEP: 60150-000 Fortaleza-CE Phone: +55 (85) 3251-1549, Fax: +55 (85) 4009-8050

E-mail:

mfacanha@yahoo.com

\begin{abstract}
Paracoccidioidomycosis is endemic in most countries of Latin America. Brazil has the greatest number of cases, with no autochthonous case registered in the state of Ceará. The cases of two patients that had never gone outside the State of Ceará and lived at least some years in the municipality of Palmácia.
\end{abstract}

Keywords: Paracoccidioidomycosis, Ceará, systemic mycosis.

[Braz J Infect Dis 2010;14(1):86-88] @Elsevier Editora Ltda.

\section{INTRODUCTION}

Paracoccidioidomycosis has been identified as an autochthonous disease in Latin American countries localized between Mexico and Argentina. $^{1,2}$ In Brazil, endemic rate varies among the regions; in general, the states from the Southern and Southeastern regions are those where there is the larger concentration of cases. Northern region was considered of low endemism in the 80s, until growth of agriculture in Amazon region, when occurred the appearance of many cases of paracoccidioidomycosis, especially, acute and subacute forms (juvenile type). Northeastern region has the lowest endemism, with the exception of the states of Maranhão and Bahia., ${ }^{3,4}$ Besides cases identification, endemic are also recognized by intradermo-reaction (IDR) with paracoccidioidin, which is estimated to be positive in $10 \%$ of the inhabitants of endemic areas. ${ }^{5}$ The register of these cases shows the presence of paracoccidioidomycosis in Ceará and calls attention to the inclusion of this disease as a differential diagnosis in cases with similar clinical manifestations.

\section{CASE REPORT 1}

A 21-year-old man, a rural worker natural and resident of Palmácia - Ceará, was admitted at São José Hospital of Infectious Diseases (HSJ) in November, 1988, complaining of a mass in the neck. A month before the admission, he noticed

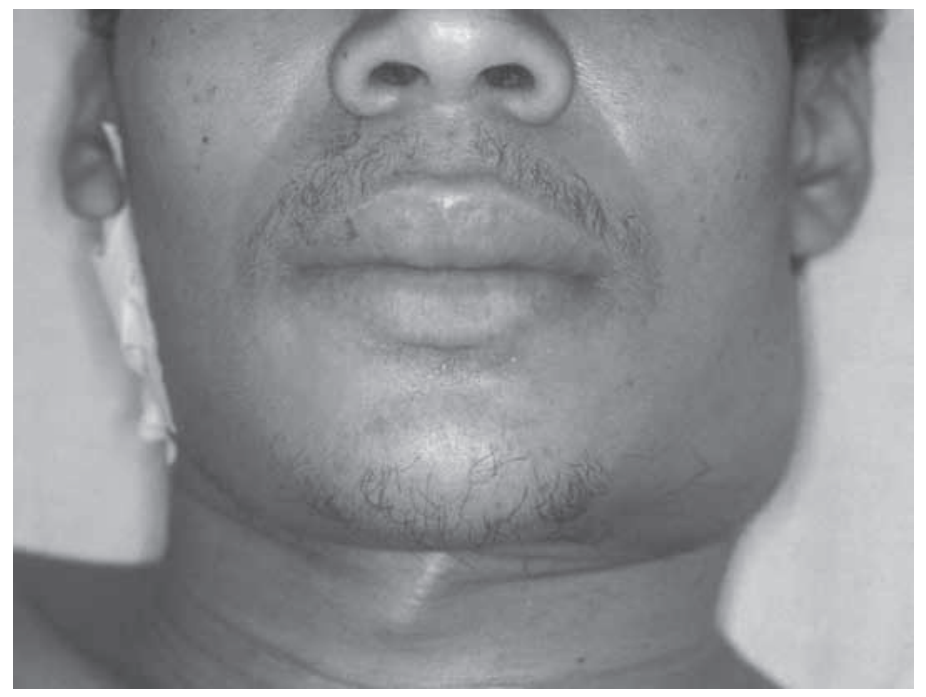

Figure 1:

Case 1 - Cervical adenomegaly. 
lymphadenopathy in right inguinal area without inflammatory signals. Ten days later, he started to present moderate fever daily, without chills, and associated with right cervical lymphadenomegaly. Physical examination revealed paleness with generalized lymphadenopathy and hepatosplenomegaly. The lymph nodes were of rubbery consistency, painless, and in right cervical and inguinal regions there were two presenting fluctuation measuring $12 \times 9 \times 9 \mathrm{~cm}$ and $8 \times 6 \times$ $4 \mathrm{~cm}$, respectively (Figure 1). The spleen edge was palpated $3 \mathrm{~cm}$ below the left costal margin, and the liver edge was $5 \mathrm{~cm}$ below the right costal margin.

Laboratory tests performed: hematocrit 28\%; hemoglobin $8.2 \mathrm{~g} / \mathrm{dL}$; white blood cells $10,000 / \mathrm{mm}^{3}$; albumin $3.36 \mathrm{~g} \%$; globulin $5.6 \mathrm{~g} \%$; urea, creatinine, glycemia, AST, ALT and bilirubin were normal. Parasitological examination of feces: Giardia lamblia and Ancylostoma spp. Urinalysis: pyuria and proteinuria. Chest X-ray: without any abnormal findings. Direct examination of secretion aspired from lymphatic ganglia, as well as histopathological examination from lymph nodes and bone marrow biopsies demonstrated Paracoccidioides brasiliensis (Figure 2). Ganglionar and bone marrow cultures were positive. The serology by agar-gel double diffusion for $P$. brasiliensis was positive with titration of 1:8. BAAR and Yersinia pestis bacterioscopy and culture were negative.

The patient was initially treated with ketoconazole during three months and later with trimethoprim-sulfamethoxazole for three more months. He also used metronidazole, mebendazole and ferrous sulfate. He evolved well, with disappearance of fever, gain of weight, progressive regression of lymphadenopathy and hepatosplenomegaly. One year after the end of the treatment, he was found asymptomatic and with normal physical examination. Serology for P. brasiliensis was positive (1:2).

\section{CASE REPORT 2}

A 44-year-old man resident of General Sampaio municipality, Ceará, agriculturist, presented an ulcerated lesion in oral mucous, near to the right first molar, associated to dry cough and fever and weight loss of $6 \mathrm{~kg}$ in seven months. The oral lesion increased and in August 25, 2007, a biopsy was performed, being diagnosed paracoccidioidomycosis. He smoked eight cigars daily and drunk moderately. He denies previous diseases. He lived in Palmácia between 1977 and 1998 and had never left Ceará.

Physical examination was normal, except for an ulcero-nodular lesion in the right side oral mucous, and a right cervical lymph node of $3 \mathrm{~cm}$ of diameter.

Laboratory tests: $\mathrm{Hb} 12.5 \mathrm{mg} / \mathrm{dL}$, Ht $38.8 \%$, anisochromia and anisocytosis. White blood cells were $7,000 / \mathrm{mm}^{3}$ with predominance of segmented neutrophils (64\%). Platelets were $215 / \mathrm{mm}^{3}$. Glycemia, urea, creatinine, AST e ALT were normal. PPD test was not reactor. BAAR research was negative in three samples. Prothrombin time 13 s, 100\%. Chest X-ray was normal, as well as abdominal ultrasound. CD4+ T cells count was 668 cells $/ \mathrm{mm} 3$ and CD $8+\mathrm{T}$ cells count was $444 / \mathrm{mm}^{3}$. Serology for HIV was negative. Hystopathology of mucous lesion obtained by biopsy and stained by Grocott's method revealed various yeasts, some of them with multiple budding resembling steering wheels, in agreement with the description of Paracoccidioides brasiliensis.

Itraconazole $200 \mathrm{mg}$ PO daily was initiated in October, 2007. In the end of January, 2008, he was considered clinically fine.

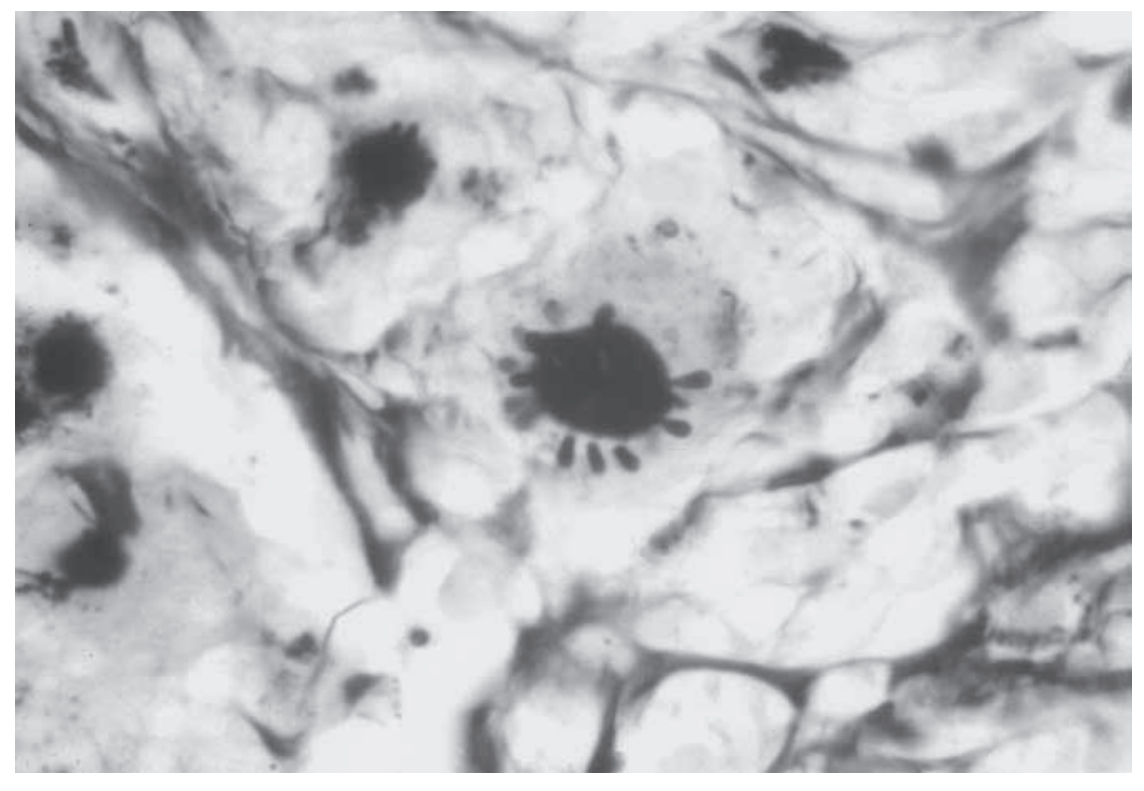

Figure 2:

Paracoccidioides brasiliensis. 


\section{DISCUSSION}

Two cases of paracoccidioidomycosis are described in individuals that had never left Ceará. The first man always lived in Palmácia municipality, and the second one had lived there for 21 years. The intradermo-reaction with paracoccidioidin was carried out in 90 residents of the area where the first one lived, being positive in 17 (18.9\%), and only two had ever left Ceará. Serology for P. brasiliensis was performed in 103 inhabitants from the same area, and was positive only in the first patient. These findings corroborate the occurrence of an autochthonous infection by $P$. brasiliensis in this area of Ceará.

In 1950, Jucá described one case of chronic disseminated form, which could be autochthonous from Ceará, but this was not made clear. This patient lived in the municipality of Pereiro, Ceará, where he worked as agriculturist until he was 21 year-old. ${ }^{6}$ In 1990, 32.1\% of 138 inhabitants from Pereiro were positive in the paracoccidioidin test. ${ }^{7}$ There were five deaths due to paracoccidioidomycosis registered in Ceará between 1980 and 1995, with no reference to the probable place where the infections were acquired. ${ }^{8}$

Palmácia is a municipality predominantly rural, with a temperate climate, mean annual temperature of $29.5^{\circ} \mathrm{C}$, altitude of $425 \mathrm{~m}$, population of 10,189 inhabitants with about $10 \%$ of urban area, having a demographic density of 105.77 inhabitants per $\mathrm{km}^{2}$ and economy based in the agriculture, mainly bananas. The state of Ceará presents other areas with similar climate and vegetation, where there can be autochthonous transmission of $P$. brasiliensis, as occurred in Pereiro. Possibly, some cases are not notified due to lack of prepare to diagnose this disease in these regions.

There are no doubts that paracoccidioidomycosis is autochthonous in Ceará probably with a low endemism. This knowledge points out the necessity of more studies to define exactly the epidemiology of this infection in the region.

\section{CONCLUSION}

The state of Ceará must be included among those who have autochthonous infections of $P$. brasiliensis and this information needs to be disseminated, allowing paracoccidioidomycosis to be included among the differential diagnosis of the patients with a suggestive clinical presentation.

\section{REFERENCES}

1. Greer DL, Restrepo AM. La epidemiologia de la paracoccidioidomicosis. Boletim da Oficina Sanitaria Panamericana 1977; 82:428-43.

2. Londero AT. Epidemiologia. In: Del Negro G, Lacaz CS, Fiorillo AM. Paracoccidioidomicose (blastomicose sul-americana). São Paulo, Sarvier, 1982; 85-90.

3. Telles Filho FQ 2001. Paracoccidioidomicose. Saúde no Paraná Boletim Epidemiológico da Secretaria Estadual da Saúde. 2001. [on line cited in April 16, 2006] Available in: http://www.saude.pr.gov.br/Vigiepi/Boletim/Inverno_2001/pcm_sesa.htm

4. Shikanai-Yasuda MA, Telles Filho FQ, Mendes RP et al. Consenso em paracoccidioidomicose. Rev Soc Bras Med Trop 2006; 39(3):297-310

5. Wanke B, Londero AT. Epidemiology of paracoccidioidomycosis infection. In: Paracoccidioidomycosis. Franco M, Lacaz CS, Restrepo-Moreno A, del Negro G (ed). Boca Raton: CRC Press 1994; pp. 109-20.

6. Marques SA. Paracoccidioidomicose: Atualização epidemiológica, clínica e terapêutica. An Bras Dermatol 2003; 78(2):135-50.

7. Jucá W. Forma pulmonar da Doença de Lutz no Ceará. Medicina, Cirurgia e Farmácia 1950; 174:470-2.

8. Diógenes MJN, Gonçalves HMG, Mapurunga ACP, Alencar KF, Andrade FB, Nogueira-Queiroz JA. Reações à histoplasmina e paracoccidioidina na Serra de Pereiro (Estado do Ceará - Brasil). Rev Inst Med Trop São Paulo 1990; 32(2):116-20.

9. Coutinho ZF, Silva D, Lazéra M et al. Mortalidade por paracoccidioidomicose no Brasil (1980-1995). Cad Saúde Pública, 2002; 18(5):1441-54. 